\title{
EXPERIMENTAL INVESTIGATIONS AND COMPUTER SIMULATIONS TO SOLVE ACOUSTIC PROBLEMS IN THE MODERN CHURCH
}

\author{
Anna SYGULSKA*, Tomasz CZERNIAK, Adrian CZARNY-KROPIWNICKI \\ Faculty of Architecture, Poznan University of Technology, Poznan, Poland \\ Received 27 September 2017; accepted 19 January 2018
}

\begin{abstract}
Architectural acoustics of contemporary sacred buildings is still an under-appreciated issue. Many contemporary churches are not functional enough due to acoustic defects which occur there. The study discusses issues of the modern Catholic church, where acoustic problems surface as high reverberant noise levels. The building under investigation, i.e. the Church of the Visitation of the Blessed Virgin Mary, is the biggest contemporary church in Poznań, Poland, as its internal volume amounts to $16,800 \mathrm{~m}^{3}$. On the basis of in situ investigations, a computer model of the church was built and a series of simulations were carried out to determine correct treatment in order to achieve satisfactory acoustic conditions. The main assumption was to find such a solution as not to affect the modernist architecture of the church.
\end{abstract}

Keywords: acoustic simulations, church acoustics, reverberation time, contemporary church, acoustic corrections.

\section{Introduction - literature overview}

Architectural acoustics is a rapidly developing scientific field. Within a building are interiors whose acoustics are inseparably linked to the basic function of the building; such buildings are called purpose-built facilities with socalled "qualified acoustics", such as opera houses, philharmonic halls, theatres, cinemas, and churches. The following paper discusses issues of acoustics of contemporary Catholic churches. The main acoustic problem occurring in this type of buildings is excessive reverberation time, which is caused by application of sound reflecting materials and lack of details. In result, the building does not serve its liturgical function as the church interior becomes noisy and the speech becomes unintelligible.

Application of acoustic treatment in an existing building is much more difficult than acoustic solutions at the design stage. In addition, acoustic treatment in architecturally acclaimed buildings is even more problematic. In the considered case, the modernist building has a certain architectural value, so any additional materials have to be introduced wisely. Special attention should be given not to ruin the architecture of the interior through application of absorptive materials without understanding its architecture. In other words, introduction of acoustically meaningful elements to improve functionality of the church should not interfere with the original architectural idea. The aim of the publication is to present an integrated acoustic-architectural process in the design of acoustic treatment of sacred buildings of an architectural value.

The issue of acoustics in modern sacred buildings was discussed in the following papers. Buenó, León, and Galindo (2012) discuss the issue of the Santa Ana Church in Mortalez in Madrid, where too long reverberation time occurs. After acoustic investigations and computer simulations were carried out, such acoustic treatment was designed as not to interfere with the original architectural idea. Horvat, Domitrovic, and Jambrosic (2011) describe acoustic treatment in two newly built churches in Croatia, and the results presented here concerned every stage of the applied acoustic treatment. Kosała and Kamisiński (2011) discuss the issue of excessive reverberation time in the St. Paul Apostole's Church in Bochnia. After acoustic investigations and computer simulations where carried out, acoustic treatment was suggested to improve the acoustic quality of the interior. Queiroz de Sant'Ana and Trombetta Zannin (2011) present acoustic issues of the São Carlos Borromeu in Curitiba on the basis of investigations and acoustic simulations.

In addition the issue of acoustics in contemporary churches is discussed in Rychtáriková, Musabuda and Ohrablo (2003), Engel and Kosała (2005), Due Schmidt and Kirkegaard (2005), Buratti, Mariani and Costarelli (2006), Engel and Kosała (2007), Carvalho and Nascimen-

${ }^{\star}$ Corresponding author. E-mail: anna.sygulska@put.poznan.pl 
to (2011), Soeta et al. (2012), Carvalho, Cruz and Pereira (2012), Engel and Kosała (2013), Schenone, Borelli and Pittaluga (2016); Kosała (2017).

This paper presents acoustic simulations based on ray tracing method. Computer simulations of interiors based on this method are used when new buildings are designed or when existing buildings need acoustic treatment. The study presented here used ODEON 11 software (Odeon, version 2011) to carry out acoustic analyses in a contemporary church with excessive reverberation time. The software is used by many authors to do research on various aspects of architectural acoustics. Weitze, Rindel, Christensen, and Gade (2002) performed simulations of the Hagia Sophia, a church whose interior design has often changed throughout centuries according to the changing function of the interior. Originally, it was a Catholic church; later, it became a mosque; at present, it is a museum. Each of these functions underwent a simulation and it was shown how acoustic conditions changed. Iannace, Berardi, and Ianniello (2015) present simulations of the interior of the Palatine Chapel, where too long reverberation time occurs. The issue of excessive reverberation time and a proposal of acoustics treatment is presented in Iannace (2016). In the Cathedral of Benevento, reverberation time impedes speech intelligibility and reception of music. Due to the historic architecture of the church, the excessive reverberation time was limited by application of ceramic systems and transparent micro-perforated sheets instead of usual sound absorbing materials.

There are other softwares used for simulations of acoustic conditions of an interior. Investigations of churches using CATT-Acoustic software are shown, among others, in the following publications. Alonso, Sendra, and Suárez (2014) examined acoustic conditions in the cathedral in Sevilla on the occasion of canonization of King San Fernando in 1671. Alvarez-Morales and Martellotta (2015) examine the influence of believers on the acoustics in a church. The article discusses the issue of location of the sound source and its position in the presbytery area. The investigations were carried out in six churches of different internal volumes. Alonso, Sendra, Suárez, and Zamarreño (2014) carried out an in-depth acoustic analysis and prepared acoustic adaptation of the Cathedral of Seville for the needs of a concert, while the paper (Berardi, 2014) is a study of dependencies between architecture and acoustic parameters for rectangular churches. Alonso, Suarez, and Sendra (2017) describe how, by means of computer simulations, acoustic conditions were recovered for each of three configurations of choir stalls, which changed their position between the $17^{\text {th }}$ and $20^{\text {th }}$ centuries. In addition designs of acoustic treatment in existing churches using acoustics simulations in CATT-Acoustic are presented in such papers as Kosała and Kamisiński (2011), Buenó et al. (2012), Gagliano, Nocera, Cicero and Gioia (2015).

In acoustic simulations, sound absorption by pews is an important factor. The issue was discussed by, among others, the following authors Desarnaulds, Carvalho and
Monay (2002), Cirillo, D'Alba, Della Crociata, and Martellotta (2007), Martellotta and Cirillo (2009), Martellotta, Della Crociata, and D'Alba (2011), Carvalho and Pino (2012).

It is crucial to assume such a model as to get results close to the actual measurements. Alonso and Martellotta (2016) brought up the subject of textiles loosely hanging in spaces, and they discussed issues of adopting proper data in computer simulations, while Martellotta and Castiglione (2011) present results of investigations into materials on church walls used as absorbers in church interiors.

\section{The Church of the Visitation of the Blessed Virgin Mary}

\subsection{Architecture}

On the cusp of the 1970s and 1980s, sacred buildings in Poland varied in terms of internal volume. There were small churches with internal volumes up to $1,500 \mathrm{~m}^{3}$, medium-size churches with average internal volumes up to $5,000 \mathrm{~m}^{3}$, and big churches with internal volumes up to $15,000 \mathrm{~m}^{3}$. It should be noted that more often than not even bigger churches were erected. The reason behind the trend was socio-political situation; a lot of housing estates were built and their residents needed churches. However, to obtain a permit to build one was a difficult task. When the permit was granted, a huge facility was built as it was quite possible that another one in the neighbouring housing estate would never come into existence. In the case of the Church of the Visitation of the Blessed Virgin Mary, when the permit had been granted, a huge two-storey facility was erected. For years, it has been a place of worship for residents of a few housing estates. The church has two independent entrances, one to the upper church and the other to the lower church, so that services can be performed in the two independent spaces at the same time.

The design of the church was created in 1997 by two architects from Warsaw, Jerzy Marek Eibl and Stanisław Sołtyk (Sobczak, 2006). Erected in years 1978-1990, it is still the biggest church in Poznan. Three functions of the facility include a liturgical function, a housing function, and an administrative function. The liturgical part takes up two spaces, i.e. the main representative hall of the upper church and the smaller zone of the lower church. As the process of obtaining permits to build religious facilities was fairly complicated, it was decided that the administrative and the housing spaces would be part of the church without a separate parsonage (Raczkowska, 2001).

The plan of the church is based on a parabola closed with an arch with internal dimensions $58.5 \mathrm{~m}$ (span of the arms of the parabola) by $42.5 \mathrm{~m}$ (axis from the top of the parabola), which results in an area of about $1,440 \mathrm{~m}^{2}$. The axial section of the building at the highest point amounts to $30 \mathrm{~m}$ (above the altar) and falls towards the vestibule. The internal volume of the upper church amounts to $16,800 \mathrm{~m}^{3}$. The body of the building is bold and quite ab- 
stract, which is characteristic of churches of the post-Second Vatican Council period. The building is covered with a shell roof with a construction leaning on steel spans, which was extraordinary at the time the church was being erected. The longest span is $50 \mathrm{~m}$ long (Marciniak, 2010), which resulted in a column free space (Figure 1). The interior of the church is dominated by ceramic and stone materials. The main parabola-based walls are made of brick - pilasters and cornices made from brick dark brown in colour, filled with lighter type in between. The wall spanning the two arms of the parabola is almost all made of glass intersected only by thin metal mullions and door frames of the entrance (Figure 2). The floor is finished with polished Swedish red granite (Raczkowska, 2001). An enormous figure of Jesus on the cross towering over the altar is made of wood. The basic furnishing element of the church are wooden pews with lightly upholstered seats. The roof is separated from the body of the church with a stream of windows, which gives an impression of the roof inertly floating over the structure of the church. The effect is a curious contrast, highlighted by warm hues of the interior and the light grey ceiling. The accordion-like structure of the ceiling is covered with plaster in a manner resembling Le Corbusier's Brutalism - severe and rough. The geometry of the plan is both symbolic and functional; as the altar is placed on the top of the parabola, it becomes a spatial highlight monopolizing attention of believers.

\subsection{Acoustic problems in the Church of the Visitation of the Blessed Virgin Mary}

The church is situated in the central part of a housing estate at a distance from the main traffic route, which isolates the church from outside noises. However, singing or speech are accompanied by a considerable amount of reverberation noise and multiple echo. Subjectively, one experiences a noisy interior where speech is hard to understand. The granite floor causes the impact sound to be clearly heard, so the sound of footsteps is amplified by echoes, which generates additional noises. The amplification system of the church is also an issue as the speakers are mounted on side walls. Due to the considerable span of the nave, they are situated too far from the listeners to serve their purpose. Thus, speech intelligibility is particularly problematic.

\section{Acoustic investigations}

The adverse acoustic conditions gave rise to speculations if acoustic treatment would yield positive results. Therefore, the purpose of the first acoustic investigation carried out in the interior was to determine values of basic acoustic parameters. A short description of characteristics of the church in comparison to four other churches in Poznań is presented in paper (Sygulska, 2014). The description of the church as a two-storey building and the issues of
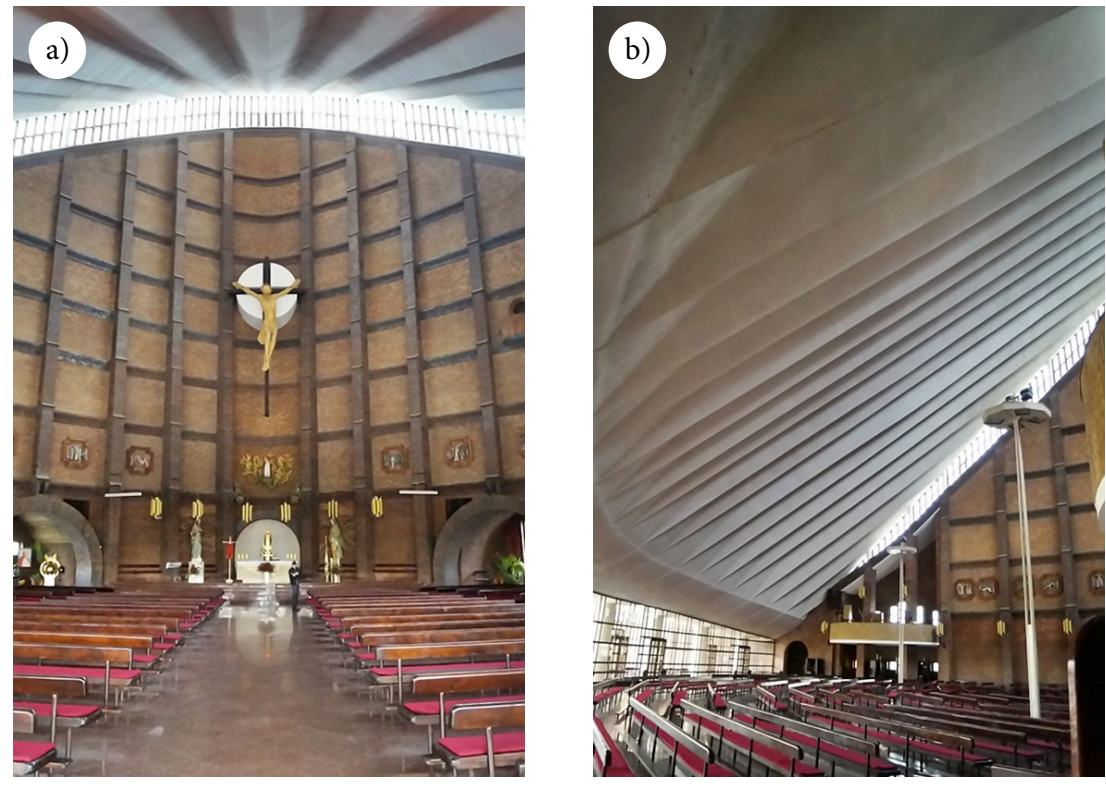

Figure 1. Photo of the church's interior: a) a view from the nave towards the presbytery; b) view from the side of the nave

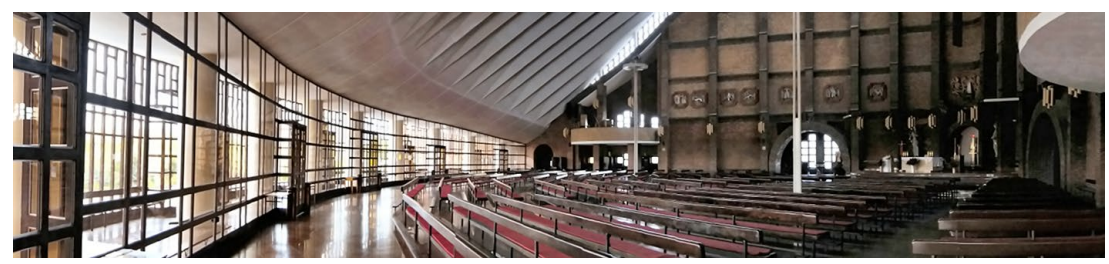

Figure 2. Panorama of the church showing the glazed entrance part in the nave 
two churches within one building were presented in paper (Sygulska, 2015). Thus obtained results rendered it possible to build a computer model in the ODEON 11 environment and to carry out predictive validity. Then, acoustic treatment was suggested to obtain acoustic parameters close to the recommended values.

\subsection{Acoustic investigations in the interior of the church}

Acoustic investigations in the church interior were carried out in compliance with recommendations presented in literature (Z. Engel, J. Engel, Kosała, \& Sadowski, 2007; Martellotta, Cirillo, Carbonari, \& Ricciardi, 2009). They were carried out by means of an omnidirectional sound source - 12 loudspeakers in dodecahedral configuration, a SVAN 945A Sound Level Meter and the DIRAC room acoustic software. The Brüel \& Kjær ZE-0948 USB Audio Interface was employed. The e-sweep signal was generated. The sound source was located in front of the altar at the height of $1.5 \mathrm{~m}$. The measurements were taken in 12 points evenly distributed in the pews. The microphone was positioned at the height of $1.1 \mathrm{~m}$, which corresponds to the height of a person sitting in a pew. As the church is symmetrical, the measuring points were chosen on one side of the nave only. The acoustic background was equal to $34 \mathrm{~dB}$. Figure 3 presents a section with marked measuring points and a sound source; Figure 4 shows the section of the church.

\subsubsection{The investigated acoustic parameters}

The analysis covered parameters (regarded in literature as basic) to evaluate acoustic properties of religious interiors; thus, $T_{30}, t_{S}, C_{80}$ and $C_{50}, D_{50}$, STI and RASTI were measured. The investigated acoustic parameters were compared with recommendations (Wróblewska \& Kulowski, 2007).

Reverberation is determined quantitatively by reverberation time, which is a basic parameter used to evaluate acoustic quality of an interior. To a great extent, it is considerably correlated with numerous acoustic parameters employed to evaluate individual acoustic aspects of an interior. Reverberation time is the parameter that is the first and foremost defined acoustic parameter of an interior. The phenomenon of reverberation time was described by Wallace Clemente Sabine as part of his statistical theory of the sound field in rooms, proclaimed in 1900 (Kulowski, 2011).

Reverberation time $R T$ is defined as the time for the sound to decay to a level $60 \mathrm{~dB}$ below its original level. It is determined on the basis of the sound decay curve. The measurements are carried out in octave bands. In practice, the measurement is taken in the range from $5 \mathrm{~dB}$ to 35 $\mathrm{dB}$ below the initial level and is multiplied by two (and is described as $T_{30}$ ). The measured reverberation time is equal to $T_{30}=5.9 \mathrm{~s}$, while the recommended reverberation time for a church of such an internal volume is equal to $T_{30}=1.5-3.3 \mathrm{~s}$ (Everest \& Pohlmann, 2009). The value of mid-frequency $T_{30}$ is even higher and amounts to $T_{30}$ $(500-1000)=7.1 \mathrm{~s}$.

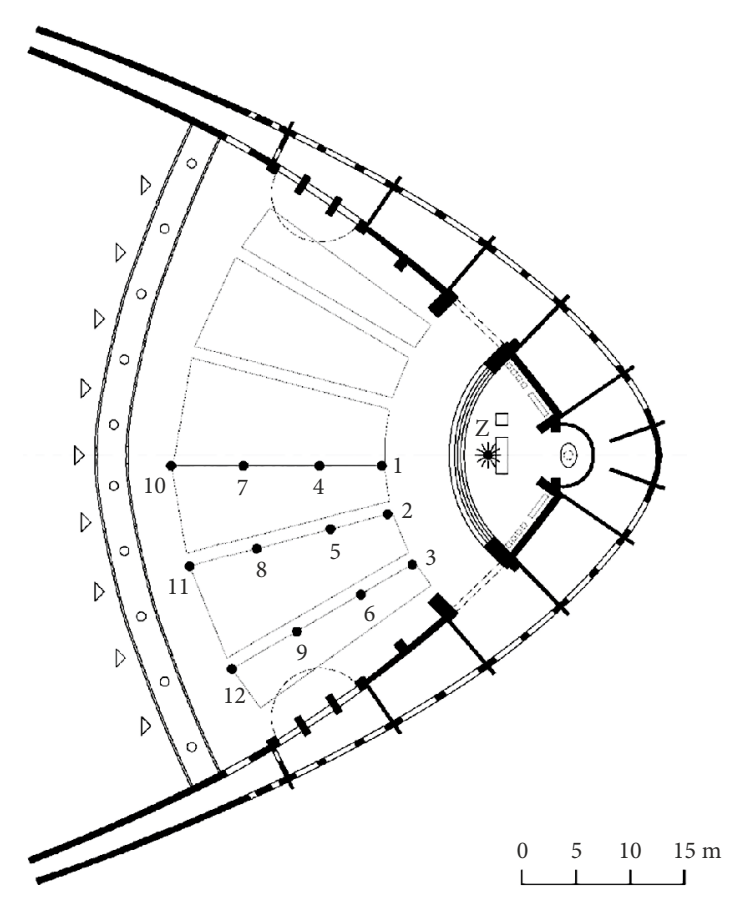

Figure 3. View of the church with marked measuring points

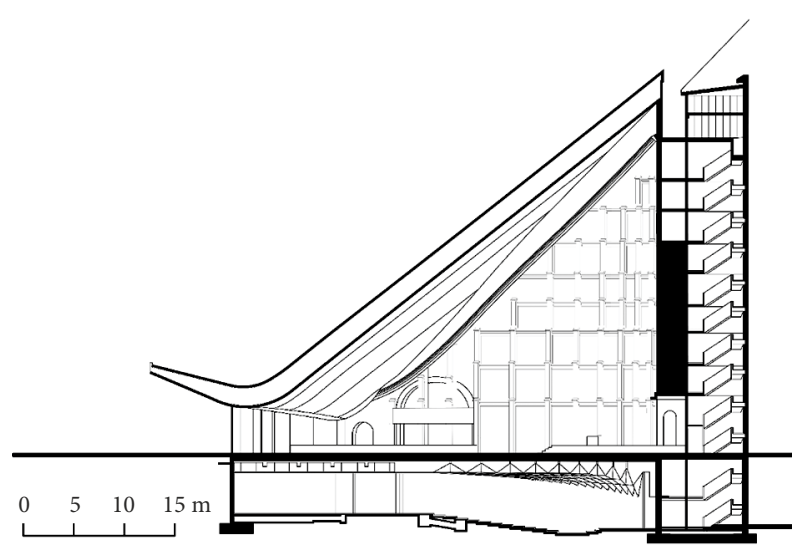

Figure 4. Section of the church

Early decay time $E D T$ is six times the duration of the sound level decrease by $10 \mathrm{~dB}$ after having switched off the sound source. It is determined on the basis of the slope of a straight line approximating to a sound decay curve in the range from 0 to $-10 \mathrm{~dB}$. EDT better than $R T$ reflects subjectively perceived reverberation of a room and has lower values in comparison with $R T$. In the investigated interior, $E D T=5.3 \mathrm{~s}$, which is a value close to the measured $R T$ and confirms the clearly noticeable reverberance.

To evaluate clarity of music, center time $t_{S}$ is used, which is defined as the time of the center of gravity of the squared impulse response. The obtained result $t_{S}=410 \mathrm{~ms}$ considerably exceeds the recommended values, which are equal to $t_{S}=120-180 \mathrm{~ms}$.

Another parameter, i.e. clarity $C_{80}$ parameter is employed to evaluate the sound quality of music; it determines aptitude for hearing details of a received piece of music. In a logarithmic scale, this is the ratio of sound en- 
ergy reaching a measurement point during the first $80 \mathrm{~ms}$ to sound energy reaching it after $80 \mathrm{~ms}$. The $C_{80}$ parameter was, as recommended in literature, averaged for 0.5 , $1,2 \mathrm{kHz}$. Following further recommendations, $C_{80}$ was determined for the front and back rows. The results show that the parameter is not fulfilled in either case. In the front row, the values oscillate between -2.6 and -8.2 from the centre of the church towards the outside, while the recommendations are from 0 to 8 . For the back row, the value of the $C_{80}$ parameter oscillates between -5.9 and -8 , while the recommended values should be between -1 and 1. General recommendations for interiors for organ music are that $C_{80}$ should be from -8 to -3 . (Wróblewska $\& \mathrm{Ku}-$ lowski, 2007). Therefore, for organ music, the parameter is fulfilled; however, a pipe organ is not provided and an electronic organ is used in the church.

Yet another parameter is clarity index $C_{50}$ used to evaluate speech intelligibility. The index is defined in the same manner as $C_{50}$. The weighted value of the $C_{50}$ index is calculated from the measurements. Octave bands $0.5,1$, $2,4 \mathrm{kHz}$ are multiplied by a weighting factor equal to 0.15 , $0.25,0.35,0.25$ for each band respectively; thus obtained values are added up (Marshall, 1996). It is recommended that thus calculated parameter $C_{50}>-2$ for speech without a sound amplification system (Abdou \& Guy, 1996). The median value $C_{50}=8.6$, but its value changes, dependent on the point, from -2 to -13 . According to (Marshall, 1996), when $C_{50}$ is equal to from -7 to -2 , speech intelligibility is poor. If $C_{50}$ is lower than -7 , speech intelligibility is bad. Values of the $C_{50}$ parameter depend on the shape of the echogram, and thus it has different values around the room (Wróblewska \& Kulowski, 2007).
Definition $D_{50}$ is another parameter employed to determine speech intelligibility; this is the ratio of energy reaching the place of sound reception within $50 \mathrm{~ms}$ to the total impulse response. Afer Wróblewska and Kulowski (2007), literature specifies that over $85 \%$ speech intelligibility occurs when $D_{50}=0.34$ (Cremer \& Müller, 1982), $D_{50}=0.4$ to 0.6 (Gimenez \& Marin, 1988), $D_{50}=0.56$ (Bradley, 1986). In the investigated church, the median value $D_{50}=0.13$. The highest value was registered in the front row, where $D_{50}=0.33$, while the lowest value occurred in point no. 9 , where $D_{50}=0.048$.

Next parameter which was used to evaluate speech intelligibility was STI (Speech Transmission Index). In the investigation, STI was calculated for the front and back rows as recommended in literature. Its values oscillate between 0.46 to 0.27 , which means that speech intelligibility is either poor (STI from 0.3 to 0.44 ) or bad (STI < 0.33). RASTI (Rapid Speech Transmission Index), which is a simplified version of STI, yields even worse results. The RASTI parameter defines two octave bands of 500 and $2000 \mathrm{~Hz}$ respectively. Its values oscillate between 0.41 to 0.23 and in most of the 12 investigated points, they do not exceed 0.3 .

The discussed parameters are shown in Table 1,2 and 3.

\section{Model calibration}

The whole of a $3 \mathrm{D}$ model of the interior of the upper church, consisting of almost 5,000 polygons, was made in an opensource programme Blender 2.76. Figures 5 and 6 show rendering generated by the programme.

Table 1. Values of acoustic parameters $T_{30}, E D T$ and $t_{S}$ obtained from in situ measurements along with recommended values

\begin{tabular}{|c|c|c|c|c|c|c|}
\hline \multicolumn{3}{|c|}{$T_{30}(\mathrm{~s})$} & \multicolumn{2}{c|}{ EDT } & \multicolumn{2}{c|}{$t_{S}(\mathrm{~ms})$} \\
\hline \multicolumn{2}{|c|}{ mean } & $500-1000$ & recommendedmean & mean & $500-1000$ & \multicolumn{2}{c|}{ mean } & recommended \\
\hline 5.9 & 7.1 & $1.5-3.3$ & 5.3 & 7.0 & 410 & $120-180$ \\
\hline
\end{tabular}

Table 2. Values of acoustic parameters $C_{80}$ and $C_{50}$ obtained from in situ measurements along with recommended values

\begin{tabular}{|c|c|c|c|c|c|c|c|}
\hline \multicolumn{4}{|c|}{$C_{80}(\mathrm{~dB})$} & \multicolumn{3}{c|}{$C_{50}(\mathrm{~dB})$} \\
\hline first row & recommended & last row & recommended & general recommendation & mean & range of variation & recommended \\
\hline-2.6 & 0 to 8 & -5.9 & -1 do1 & organ music & -8.6 & -1.8 to & $>-2$ \\
-4.5 & & -7.3 & & -8 to -3 & & -13 & \\
-8.2 & & -8 & & oratory music & & & \\
& & & & -3 to 6 & & & \\
\hline
\end{tabular}

Table 3. Values of acoustic parameters $D_{50}$, STI and RASTI obtained from in situ measurements along with recommended values

\begin{tabular}{|c|c|c|c|c|c|c|c|}
\hline \multicolumn{2}{|c|}{$D_{50}$} & \multicolumn{2}{c|}{ STI femmale } & \multicolumn{2}{c|}{ STI male } & \multicolumn{3}{c|}{ RASTI } \\
\hline \multirow{2}{*}{ mean } & recommended & first row & last row & first row & last row & first row & last row \\
\hline 0.13 & \multirow{2}{*}{0.4 do 0.6 } & 0.46 & 0.36 & 0.45 & 0.35 & 0.41 & 0.31 \\
& & 0.39 & 0.33 & 0.38 & 0.31 & 0.33 & 0.27 \\
& & 0.28 & 0.31 & 0.27 & 0.30 & 0.23 & 0.24 \\
\hline
\end{tabular}




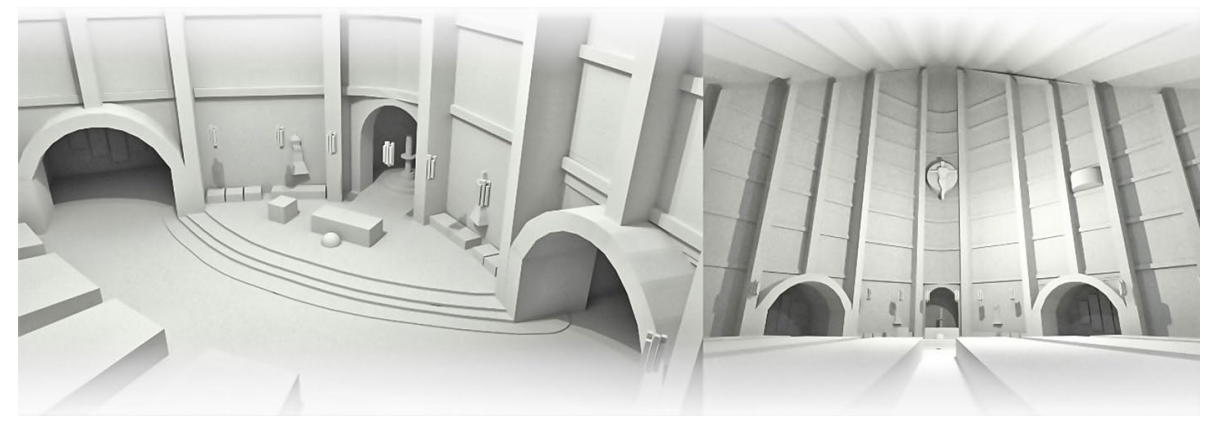

Figure 5. Bird-eye view onto the presbytery area and a view one side of the church towards the altar

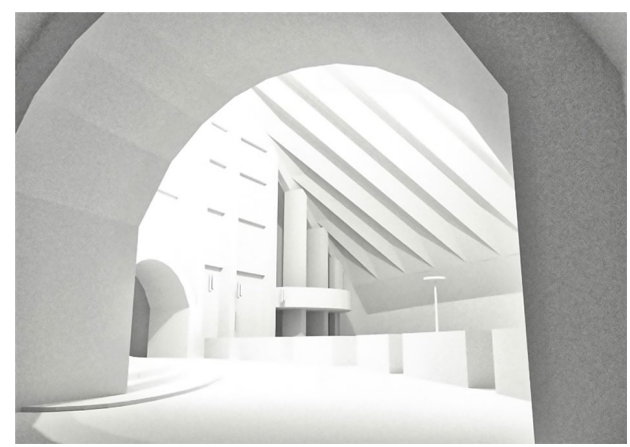

Figure 6. View from the presbytery area towards the nave

Reconstruction of the actual state of the analyzed area was possible owing to precise control over the points and dimensions from the construction documentation, i.e. the plans and cross-section, as well as in situ architectural inventory, which included verification of dimensions from the construction documentation and description of finishes. Observation of the architectural structure revealed a considerable influence of the geometrical accordion-like ceiling on subjective perception of the acoustics, and the results of the measurements of the reverberation time $T_{30}$ parameter. Therefore, during construction of the $3 \mathrm{D}$ model, special attention was paid to the precise representation of the structure of the ceiling.

In practice, a very precise transfer of an actual (and almost infinite) number of details of a building into the environment of an operating system is impossible. Stateof-the-art techniques such as photogrammetry require too much computer power compared to the potential of computers that are currently available. As the trials showed, in the case of the investigated internal volume $\left(16,800 \mathrm{~m}^{3}\right)$ too detailed representation of architectural details does not yield more precise results. Bearing it in mind, a lowpoly model was prepared; the sculpture above the altar was realized using 116 polygons, the apse -219 polygons, while the details were compensated for by a sound scattering coefficient. The issue of the pews was solved by means of sound absorption parameters suggested by (Carvalho \& Pino, 2012). An important aspect of computer simulations by ray tracing method is elimination of all imprecisions of connections between angles. The investigated space must be completely limited by the planes of the model to prevent the rays from escaping and, in effect, the loss and distortion of data. The tool (3D Investigation Rays) returns coordinates of lost rays, which renders it possible to precisely locate the problem. In the $3 \mathrm{D}$ model used for the simulation, the number of lost rays was 0 .

To carry out simulations of acoustic parameters of the church interior, ODEON 11 programme was used. The conversion from Blender to SketchUp Pro 2015 was carried out by means of DXF format; next, SU2Odeon Plugin for Trimble was used to import the object into ODEON. The method rendered it possible to keep geometry and scale unchanged, and to assign corresponding layers to planes in the intuitive editor of SketchUp, compatible with ODEON. The model was divided into 16 layers, to which 10 materials were assigned (Table 4); input configurations were those predefined in ODEON. Figure 7 shows a cross-section with a perspective; the colours represent individual layers with assigned materials.

To enable the results of the simulations to be close to the actual measurements, the receivers and the omnidirectional sound source were placed in localizations precisely corresponding to those from in situ experiments. It should be highlighted that due to the symmetrical (according to the longitudinal axis) layout of the church, the receivers were placed only on one side (Figure 3).

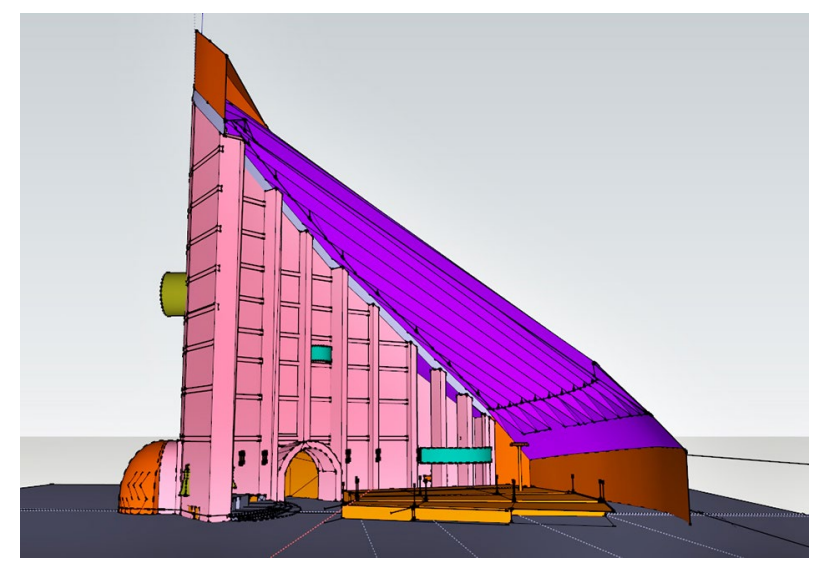

Figure 7. Cross-section with a perspective - the colours represent individual layers 
Table 4. Material properties selected for the simulation

\begin{tabular}{|c|c|c|c|c|c|c|c|c|c|c|}
\hline $\begin{array}{c}\text { Layer } \\
\text { in ODEON }\end{array}$ & $\begin{array}{l}\text { walls, } \\
\text { pilasters, } \\
\text { cornices }\end{array}$ & ceiling & floor & $\begin{array}{c}\text { area } \\
\text { taken up by } \\
\text { pews }\end{array}$ & glazings & $\begin{array}{l}\text { Figures, } \\
\text { sculptures }\end{array}$ & balconies & apse & altar & $\begin{array}{l}\text { lighting } \\
\text { poles }\end{array}$ \\
\hline $\begin{array}{l}\text { Type of } \\
\text { material }\end{array}$ & $\begin{array}{l}\text { clinker } \\
\text { brick }\end{array}$ & plaster & $\begin{array}{c}\text { marble } \\
\text { floor } \\
\text { tiles }\end{array}$ & \begin{tabular}{|c|} 
partially wooden, \\
partially \\
upholstered
\end{tabular} & glass & stone & $\begin{array}{l}\text { clinker } \\
\text { brick }\end{array}$ & plaster & $\begin{array}{c}\text { marble partially } \\
\text { covered with a } \\
\text { textile }\end{array}$ & steel \\
\hline Area $\left[\mathrm{m}^{2}\right]$ & 3378.0 & 2212.5 & 1593.2 & 1092.8 & 337.4 & 89.7 & 88.9 & 62.8 & 27.3 & 17.1 \\
\hline $\begin{array}{l}\text { Total area } \\
\text { in } \%\end{array}$ & 38.0 & 24.9 & 17.9 & 12.3 & 3.8 & 1.0 & 1.0 & 0.7 & 0.3 & 0.2 \\
\hline \multicolumn{11}{|c|}{$\alpha$ coefficient } \\
\hline $125 \mathrm{~Hz}$ & 0.03 & 0.11 & 0.01 & 0.106 & 0.35 & 0.01 & 0.03 & 0.11 & 0.36 & 0.30 \\
\hline $250 \mathrm{~Hz}$ & 0.03 & 0.08 & 0.01 & 0.135 & 0.25 & 0.01 & 0.03 & 0.08 & 0.44 & 0.25 \\
\hline $500 \mathrm{~Hz}$ & 0.03 & 0.07 & 0.01 & 0.130 & 0.18 & 0.02 & 0.00 & 0.07 & 0.31 & 0.20 \\
\hline $1000 \mathrm{~Hz}$ & 0.04 & 0.06 & 0.01 & 0.230 & 0.12 & 0.02 & 0.04 & 0.06 & 0.29 & 0.10 \\
\hline $2000 \mathrm{~Hz}$ & 0.05 & 0.14 & 0.02 & 0.320 & 0.07 & 0.02 & 0.05 & 0.05 & 0.39 & 0.10 \\
\hline $4000 \mathrm{~Hz}$ & 0.07 & 0.1 & 0.02 & 0.300 & 0.04 & 0.02 & 0.07 & 0.05 & 0.25 & 0.15 \\
\hline \multicolumn{11}{|c|}{ Scattering coefficient } \\
\hline $\begin{array}{l}\text { Scattering } \\
\text { coefficient }\end{array}$ & 0.1 & 0.05 & 0.05 & 0.6 & 0.05 & 0.1 & 0.1 & 0.05 & 0.1 & 0.05 \\
\hline
\end{tabular}

The very first simulations of reverberation time $\left(T_{30}\right)$ with approximations according to Sabine's formula and Eyring's formula corresponded to a great extent with the results of in situ investigations. The only considerable discrepancies occurred for reverberation time $T_{30}$ for high frequencies. Within the model calibration, the coefficient assigned to the pews was changed for more appropriate for partially wooden and partially upholstered furniture. After the correction, the results of measurements in all the measuring points corresponded to the expected values, i.e. the median error was equal to $1.94 \%$ (Table 5) and a graph (Figure 8).

\subsection{Simulations after acoustic treatment}

The already calibrated model, meeting the established requirements (within the assumed error), underwent acoustic treatment, i.e. replacement of some of materials. Due to a high architectural value of the building, it was natural that the treatment had to be as non-invasive as possible, without alteration to elements of the structure, to retain

Table 5. Comparison of results of $T$ for simulations and in situ measurements

\begin{tabular}{|l|c|c|c|c|c|c|}
\hline \multicolumn{7}{|c|}{$T_{30}(\mathrm{~s})$ (average) } \\
\hline & 125 & 250 & 500 & 1000 & 2000 & 4000 \\
\hline $\begin{array}{l}\text { ODEON computer } \\
\text { simulation }\end{array}$ & 7 & 7.92 & 7.97 & 6.21 & 4.07 & 2.46 \\
\hline In situ measurements & 6.99 & 7.98 & 8.01 & 6.27 & 3.94 & 2.31 \\
\hline error [\%] & 0.14 & 0.76 & 0.50 & 0.97 & 3.19 & 6.10 \\
\hline Median of the error [\%] & \multicolumn{7}{|c|}{1.94} \\
\hline
\end{tabular}

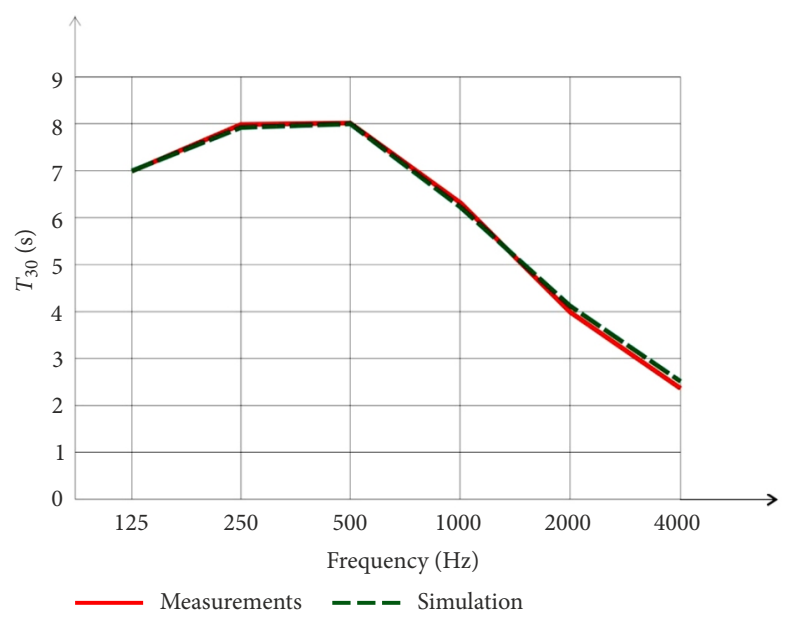

Figure 8. Comparison of reverberation time $T_{30}$ in the frequency function for in situ investigations and an ODEON computer simulation

the unique character of the sacrum. All the brick surfaces in the interior have apparently great potential. However, the tiniest change would not only degrade the quality of the space but it would also generate enormous costs and would be hard to put into practice. One of the best possible solutions was to cover the ceiling with acoustic plaster. At present, the ceiling is finished with traditional cementlime plaster (Figure 9). Due to its accordion-like structure, the area of the ceiling is significant (25\%) compared to other surfaces in the nave (Table 4).

The assumption was that this type of modernization was to yield a measurable effect, affecting reverberation time $T_{30}$ in particular, which would improve the speech transmission index (STI). The 3D model, imported into 
Table 6. Comparison of types of acoustic plaster used in the simulation

\begin{tabular}{|l|c|c|c|c|c|c|}
\hline Types of acoustic plaster used in the simulation & $125 \mathrm{~Hz}$ & $250 \mathrm{~Hz}$ & $500 \mathrm{~Hz}$ & $1000 \mathrm{~Hz}$ & $2000 \mathrm{~Hz}$ & $4000 \mathrm{~Hz}$ \\
\hline Sherff P0-1 $20 \mathrm{~mm}$ & 0.25 & 0.30 & 0.60 & 0.65 & 0.65 & 0.80 \\
\hline Sto-Akustikputz $25 \mathrm{~mm}$ & 0.08 & 0.24 & 0.62 & 0.89 & 0.88 & 0.83 \\
\hline Sto-Akustikputz $15 \mathrm{~mm}$ & 0.1 & 0.21 & 0.47 & 0.68 & 0.67 & 0.74 \\
\hline Sherff P0-1 10 mm & 0.15 & 0.20 & 0.30 & 0.45 & 0.60 & 0.70 \\
\hline Sonacoustic CL $25 \mathrm{~mm}$ & 0.15 & 0.50 & 0.85 & 0.95 & 0.85 & 0.95 \\
\hline
\end{tabular}

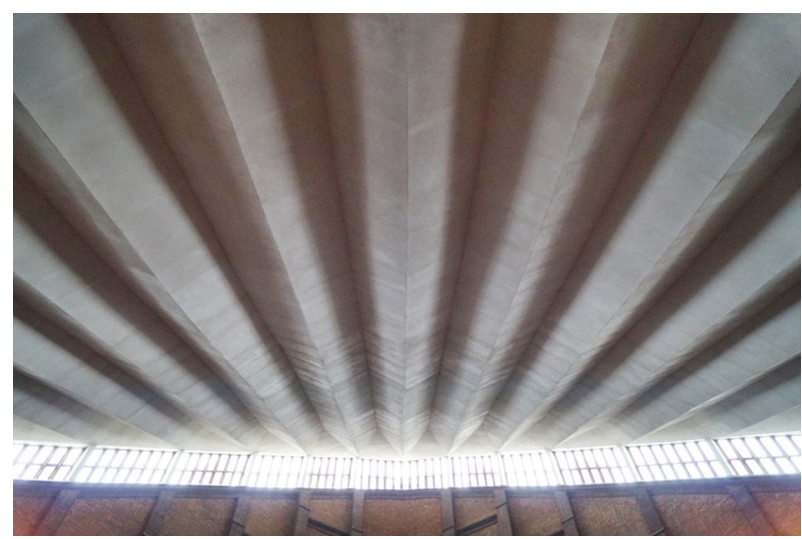

Figure 9. View of the accordion-like structure of the ceiling

ODEON, rendered it possible to assign new sound absorption parameters $(\alpha)$ to the ceiling, and it enabled a simulation for each configuration (Table 6). For the purpose of the investigation five types of plaster were chosen, while the assumed technical specification was the one provided by the manufacturer. Due to specificity of the ODEON programme, the simulation excluded materials with sound absorption coefficient $(\alpha)$ higher than 1 as the input data in ODEON must be within 0 to 1 . All the simulations were carried out with settings of the sound source and receivers identical to those during calibration, and the same input ray parameters were assumed (the number and nature of reflections - ray tracing method).

\section{Analysis of the results}

On the basis of thus obtained results, it was concluded that the result closest to the expected values, i.e. reverberation time $T_{30}$ in all investigated frequencies within the range from 1.5 to 3, can be achieved when Sherff P0-1 plaster (at thickness of $20 \mathrm{~mm}$, Figure 10) is applied. The Sonacoustic CL plaster of $25 \mathrm{~mm}$ thickness absorbs sounds better for frequency $=250 \mathrm{~Hz}$, but it hardly absorbs sounds for frequency $=125 \mathrm{~Hz}$.

If acoustic treatment employs $20 \mathrm{~mm}$ thick Sherff P0-1 20 plaster, reverberation time $T_{30}$ can be reduced by an average of 55\% compared to the actual state. The results are particularly favourable for medium and high frequencies, for which the results fell into the optimal range. As for low frequency, the improvement was by $38.7 \%$ on average, but the reverberation time $\left(T_{30}\right)$ could not reach the assumed values. Still, the results can be described as satisfactory if we consider the purpose of the adapted space and the range of the simulated adaptation (Figure 11).

For the assumed acoustic treatment, the mean reverberation time $T_{30}=2.5 \mathrm{~s}$, which is compliant with recommendations stating that $T_{30}$ should be within the range between 1.5 to $3.3 \mathrm{~s}$. The value of Early Decay Time EDT is also favourable (Figure 12). The median value of $E D T=$ $2.5 \mathrm{~s}$, i.e. the same as $T_{30}$. Literature suggests that the difference between $E D T$ and $R T$ should not be greater than 10\% (Wróblewska \& Kulowski, 2007).

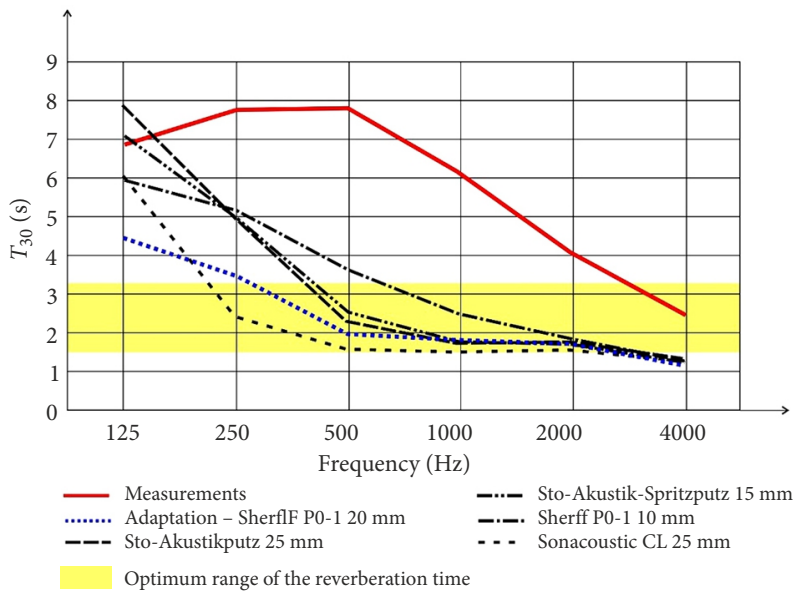

Figure 10. Graph of reverberation time $T_{30}$ in the frequency function for different types of acoustic plaster

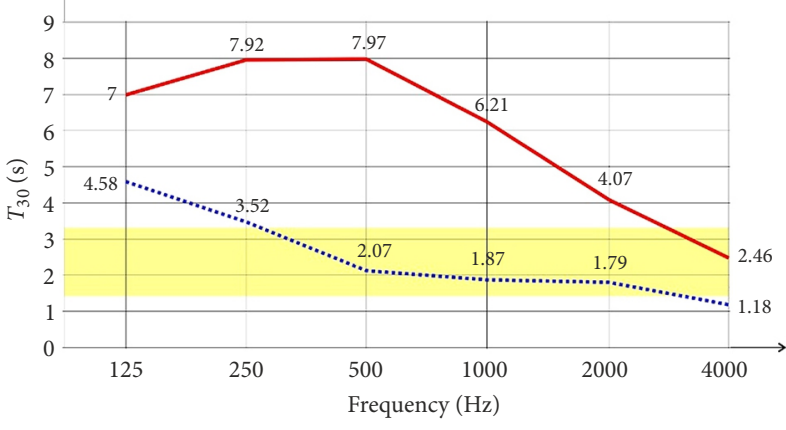

Measurements before adaptation $\quad$......... Simulation with adaptation Optimum range of the reverberation time

Figure 11. Comparison of reverberation time $T_{30}$ in the frequency function for in situ measurements and simulation with acoustic adaptation using $20 \mathrm{~mm}$ thick Sherff P0-1 plaster 
The center time $t_{S}$ reached the median value of $165 \mathrm{~ms}$, which is within the range of values recommended for churches of the investigated internal volume, i.e. 120$180 \mathrm{~ms}$. There is considerable improvement (Figure 13) in comparison with the results from the measurements, where the median value was equal to $410 \mathrm{~ms}$.

The value of another parameter, i.e. clarity index $C_{80}$ (Figure 14), is also improved compared to the state from before the treatment. According to recommendations in literature, the parameter was averaged for $0.5,1,2 \mathrm{kHz}$ and $C_{80}$ was defined for the front and back rows (Table 5). The parameter meets the recommendations for both the front and back rows.

Clarity index $C_{50}$ for octave bands $0.5,1,2,4 \mathrm{kHz}$ was multiplied by weighted coefficient equal to $0.15,0.25,0.35$, 0.25 for each band respectively. Thus obtained results were added up (Marshall, 1996). Before the treatment, the parameter was considerably exceeded; in some measuring points, $C_{50}=-13 \mathrm{~dB}$. After the treatment, in most points $C_{50}>-2 \mathrm{~dB}$, which shows that the recommendations were fulfilled (Figure 15).

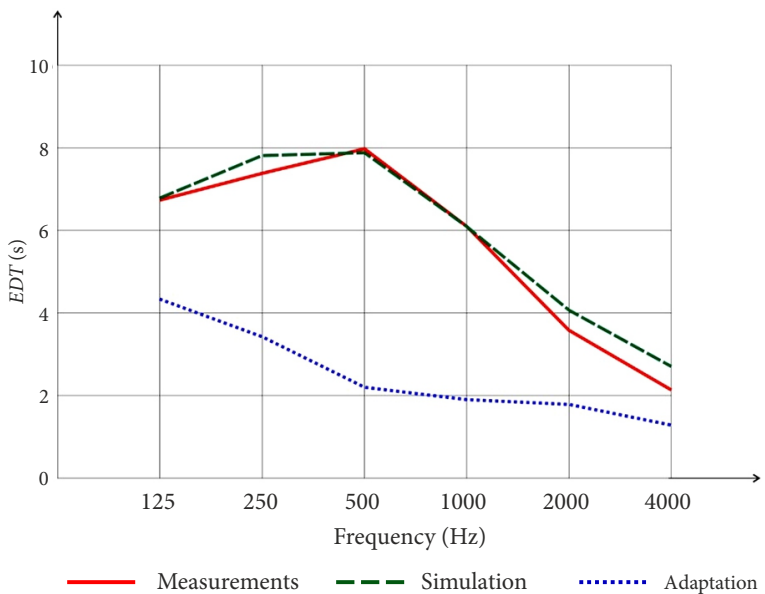

Figure 12. Graph of early decay time EDT in the frequency range - comparison of results of in situ measurements, simulation and simulation with acoustic treatment

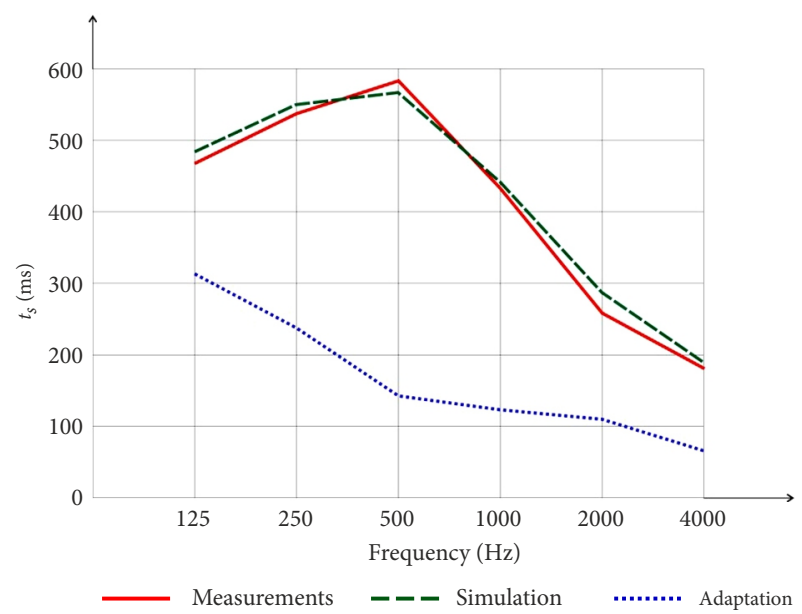

Figure 13. Graph depicting center time $t_{S}$ in the frequency function - comparison of in situ measurements, simulation and simulation with acoustic treatment

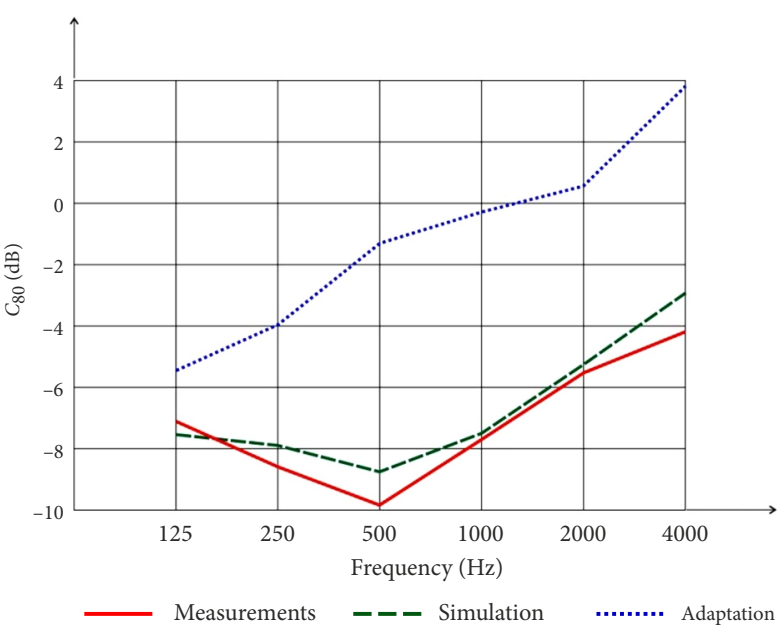

Figure 14. Graph of clarity index $C_{80}$ in the frequency range - comparison of in situ measurements, simulation and simulation with acoustic adaptation

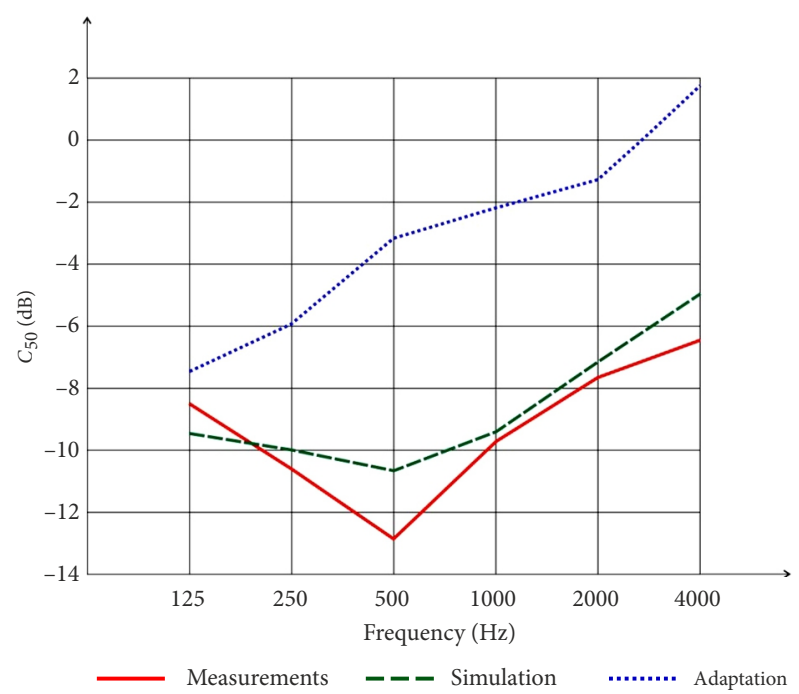

Figure 15. Graph of Clarity $C_{50}$ in the frequency function comparison of in situ measurements, simulation and simulation with acoustic adaptation

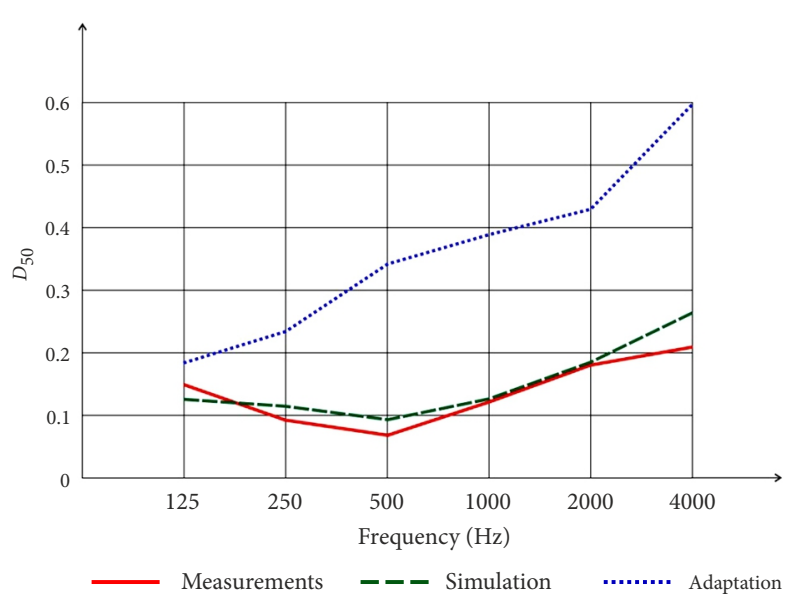

Figure 16. Graph of $D_{50}$ in the frequency range - comparison of in situ measurements, simulation and simulation with acoustic treatment 
Table 7. Values of acoustic parameters $T_{30}, E D T$ and $t_{S}$ obtained in the simulation after acoustic treatment including recommended values

\begin{tabular}{|c|c|c|c|c|c|c|}
\hline \multicolumn{3}{|c|}{$T_{30}(\mathrm{~s})$} & \multicolumn{2}{c|}{ EDT } & \multicolumn{2}{c|}{$t_{S}(\mathrm{~ms})$} \\
\hline mean & $500-1000$ & recommended mean & mean & $500-1000$ & mean & recommended \\
\hline 2.5 & 2.0 & $1.5-3.3$ & 2.5 & 2.1 & 165 & $120-180$ \\
\hline
\end{tabular}

Table 8. Values of acoustic parameters $C_{80}$ and $C_{50}$ obtained in the simulation after acoustic treatment including recommended values

\begin{tabular}{|c|c|c|c|c|c|c|c|}
\hline \multicolumn{5}{|c|}{$C_{80}(\mathrm{~dB})$} & \multicolumn{3}{c|}{$C_{50}(\mathrm{~dB})$} \\
\hline first row & recommended & last row & recommended & general recommendation & mean & range of variation & recommended \\
\hline 2.1 & 0 do 8 & 0.8 & -1 do1 & organ music & -0.96 & 2.66 to & $>-2$ \\
2.4 & & 0.6 & & -8 do -3 & & -4.86 & \\
0.8 & & -0.4 & & organ music & & & \\
& & & & -3 do 6 & & & \\
\hline
\end{tabular}

Table 9. Values of acoustic parameters $D_{50}$, STI and RASTI obtained in the simulation after acoustic treatment including recommended values

\begin{tabular}{|c|c|c|c|c|c|c|c|}
\hline \multicolumn{2}{|c|}{$D_{50}$} & \multicolumn{2}{c|}{ STI femmale } & \multicolumn{2}{c|}{ STI male } & \multicolumn{3}{c|}{ RASTI } \\
\hline \multirow{2}{*}{ mean } & recommended & first row & last row & first row & last row & first row & last row \\
\hline \multirow{2}{*}{0.36} & 0.4 do 0.6 & 0.61 & 0.51 & 0.59 & 0.49 & 0.55 & 0.46 \\
& & 0.62 & 0.52 & 0.60 & 0.50 & 0.56 & 0.46 \\
& & 0.58 & 0.49 & 0.57 & 0.47 & 0.52 & 0.44 \\
\hline
\end{tabular}

Definition $D_{50}$ reached much better values than before the acoustic treatment (Figure 16). The median value $D_{50}=0.36$. According to (Cremer \& Müller, 1982), this is the value which enables listeners to understand $85 \%$ of speech. In the first row, $D_{50}=0.55$, while in point $9, D_{50}=$ 0.19 . There is considerable improvement, especially in point no.9, where $D_{50}=0.048$ before the treatment.

Speech intelligibility expressed in STI and RASTI parameters achieved good results (Table 5). STI female in the first row amounts to 0.6 on average, while in the back row, it amounts to 0.5. STI male in the first row amounts to 0.58 , while in the back row, it amounts to 0.48 . The results denote fair to good speech intelligibility. In contrast, RASTI in the first row amounts to 0.54 , while it amounts to 0.45 in the back row, which also denotes good speech intelligibility.

The parameters discussed above after acoustic treatment are shown in Tables 7, 8 and 9.

\section{Conclusions}

The paper discussed a case of a contemporary church with a considerable volume. Subjective impressions of reverberant noise in the church were confirmed by investigations which revealed notably exceeded reverberation time. The church does not use organs and the interior is not employed for concert purposes. Therefore, it was vital to shorten the excessive reverberation time and, in effect, eliminate reverberant noise. Another important issue was to improve speech intelligibility. It was decided that an acoustic simulation would be carried out using ray trac- ing method to design a solution correcting acoustic conditions in the interior. In the case under investigation, the acoustic treatment involved the use of acoustic plaster as such a solution would not interfere with the architecture of the church. In addition, the accordion-like structure of the ceiling, which was to be covered with acoustic plaster, constitutes a substantial part of the church's surface.

In the considered case, the chosen acoustic plaster turned out effective. Before the treatment, $T_{30}=5.9 \mathrm{~s}$, whereas after the treatment $T_{30}=2.7 \mathrm{~s}$. Reverberation time for mean frequencies amounted to $T_{30}(500-1000)=$ $7.1 \mathrm{~s}$, while after the treatment, $T_{30}(500-1000)=1.97 \mathrm{~s}$. In consequence, reverberation time values, especially in mean frequencies, considerably improved. These are values which are clearly heard when considered subjectively.

Particularly good results and considerable improvement for parameters $T_{30}, E D T, C_{80}, t_{S}, C_{50}, D_{50}$ were obtained for $500 \mathrm{~Hz}$. The measurements reveal that for this frequency results are particularly unfavourable and worse from the other octave bands. After acoustic adaptation, results for the parameters for this frequency are within the recommended range.

Acoustic defects resulting from too long reverberation time increase in proportion to the increase in the volume of a building. Thus, especially if a church of a huge volume is designed, acoustics of the interior should be definitely suggested at the design stage. Correction of acoustic defects after erection of a church is troublesome and often hard to put into practice due to high costs. Ray method based programmes are inestimable in terms of designing a new building or preparation of acoustic treatment of an 
existing building. In the considered case, the replacement of plaster on the ceiling does not interfere with the architecture of the church. It is clearly seen that simple solutions can make an interior acoustically functional without compromising the original architectural idea.

\section{References}

Abdou, A., \& Guy R. W. (1996). Spatial information of sound fields for room-acoustics evaluation and diagnosis. Journal of the Acoustical Sociaty of America, 100(5), 3215-3226. https://doi.org/10.1121/1.417205

Alonso, A., Sendra, J. J., Suárez, R., \& Zamarreño, T. (2014). Acoustic evaluation of the cathedral of Seville as a concert hall and proposals for improving the acoustic quality perceived by listeners, Journal of Building Performance Simulation, 7(5), 360-378.

https://doi.org/10.1080/19401493.2013.848937

Alonso, A., Sendra, J. J., \& Suárez, R. (2014, September). Sound space reconstruction in the Cathedral of Seville for major feasts celebrated around the main chancel. Proceedings of Forum Acusticum, Krakow, Poland.

Alonso, A., \& Martellotta, F. (2016). Room acoustic modelling of textile materials hung freely in space: from the reverberation chamber to ancient churches. Journal of Building Performance Simulation, 9(5), 469-486.

https://doi.org/10.1080/19401493.2015.1087594

Alonso, A., Suárez, R., \& Sendra, J. J. (2017). Virtual reconstruction of indoor acoustics in cathedral: The case of the Cathedral of Granada. Building Simulation, 10(4), 431-446.

https://doi.org/10.1007/s12273-016-0342-z

Alvarez-Morales, L., \& Martellotta, F. (2015). A geometrical acoustic simulation of the effect of occupancy and source position in historical churches. Applied Acoustics, (91), 4758. https://doi.org/10.1016/j.apacoust.2014.12.004

Berardi, U. (2014), Simulation of acoustical parameters in rectangular churches. Journal of Building Performance Simulation, 7(1), 1-16. https://doi.org/10.1080/19401493.2012.757367

Bradley, J. S. (1986). Predictors of speech intelligibility in rooms. Journal of the Acoustical Society of America, 80(30), 837-845. https://doi.org/10.1121/1.393907

Buenó, A. M., León, A. L., \& Galindo, M. (2012). Acoustic Rehabilitation of the Church of Santa Ana in Moratalaz, Madrid. Archives of Acoustics, 37(4), 435-446. https://doi.org/10.2478/v10168-012-0055-y

Buratti, C., Mariani, R., \& Costarelli, I. (2006, July). The "Maria Regina Della Pace" church in Perugia: acoustic measurements and correction design. The Thirteen International Congress of Sound and Vibration, ICSV13-Vienna, Austria.

Carvalho, A. P. O., \& Pino, J. S. O. (2012, August). Sound absorption of church pews. Proceedings of a meeting Inter Noise, New York City, USA.

Carvalho, A. P. O., Cruz M. T., \& Pereira, G. C. G. (2012, July). Acoustic rehabilitation of middle twentieth century Portuguese churches. ICSV19, Vilnus, Lithuania.

Carvalho, A. P. O., \& Nascimento, B. F. O. (2011, June). Acoustical characterization of the underground chapels of the new Holy Trinity church in the Fatima shrine, Portugal. Proceedings of Forum Acusticum, Aalborg, Denmark (pp. 1429-1434).

Cirillo, E., D’Alba, M., Della Crociata, S., \& Martellotta, F. (2007, September). On-site measurements of absorption coefficients of pews with and without occupation. Satellite Symposium of the 19th International Congress on Acoustics, Seville, Spain.
Cremer, L., \& Müller, H. (1982). Principles and applications of room acoustics (Vol. 1). London - New York: Applied Science Publisher.

Desarnaulds, V., Carvalho, A. P. O., \& Monay, G. (2002). Church acoustics and the influence of occupancy. Building Acoustics, 9(1), 29-47. https://doi.org/10.1260/135101002761035726

Due Schmidt, A. M., \& Kirkegaard, P. H. (2005). From architectural acoustics to acoustical architecture using computer simulation, Building Acoustics 12(2), 85-98. https://doi.org/10.1260/1351010054037965

Engel, Z., Engel, J., Kosała, K., \& Sadowski, J. (2007). Podstawy akustyki obiektów sakralnych. Kraków: ITE (in Polish).

Engel, Z., \& Kosała, K. (2005). Acoustic properties of the selected churches in Poland. Mechanics, 24(3), 173-181.

Engel, Z., \& Kosała, K. (2007). Index method of the acoustic quality assessment of sacral buildings. Archives of Acoustics, 32(3), 455-474.

Engel, Z., \& Kosała, K. (2013). Assessing the acoustic properties of Roman Catholic churches: A new approach. Applied Acoustics, 74(10), 1144-1152. https://doi.org/10.1016/j.apacoust.2013.03.013

Everest, F. A., \& Pohlmann, K. C. (2009). Master handbook of acoustics (5th ed.). Mc Graw Hill, USA.

Gagliano, A., Nocera, F., Cicero, A., \& Gioia, M. C. (2015). Proposals and analysis of the effects of acoustic corrections in a modern church. Building Acoustic, 22(3+4), 143-162. https://doi.org/10.1260/1351-010X.22.3-4.143

Gimenez, A., \& Marin, A. (1988). Analysis and assessment of concert halls. Applied Acoustics, (25), 235-241. https://doi. org/10.1016/0003-682X(88)90059-X

Horvat, M., Domitrovic, H., \& Jambrosic, K. (2011). The improvement of acoustic situation in two modern churches, Proceedings of Forum Acusticum, Dania, Aalborg, 1439-1444.

Iannace, G. (2016). Acoustic correction of monumental churches with ceramic material: The case of the Cathedral of Benevento (Italy). Journal of Low Frequency Noise, Vibration and Active Control, 35(3), 230-239.

https://doi.org/10.1177/0263092316661028

Iannace, G., Berardi, U., \& Ianniello, C. (2015). Study of a historical church based on acoustic measurements and computer simulation. The $22^{\text {nd }}$ International Congress on Sound and Vibration, Florence, Italy.

Kosała, K., \& Kamisiński, T. (2011). Akustyka wielofunkcyjna wnętrz sakralnych, Czasopismo Techniczne/Politechnika Krakowska; Seria: Architektura. Zeszyt (11): 115 -122. (in Polish).

Kosała, K. (2017). A comparative analysis of the index assessment of church acoustics using RASTI and STI. Czasopismo Techniczne/Politechnika Krakowska. Seria: Architektura. Zeszyt, (6): 5-19. (in Polish).

Kulowski, A. (2011). Akustyka sal, zalecenia projektowe dla architektów (pp. 59-60). Wydawnictwo Politechniki Gdańskiej (in Polish).

Marshall, L. G. (1996). An acoustics measurement program for evaluating auditoriums based on the early/late sound energy ratio. The Journal of the Acoustical Society of America, 4, 22512261.

Martellotta, F., Della Crociata, S., \& D’Alba, M. (2011). On site validation of sound absorption measurements of occupied pews, Applied Acoustics, 72(12), 923-933. https://doi.org/10.1016/j.apacoust.2011.06.001

Martellotta, F., \& Cirillo, E. (2009). Experimental studies of sound absorption by church pews, Applied Acoustics, 70, 441449. https://doi.org/10.1016/j.apacoust.2008.05.006 
Martellotta, F., \& Castiglione, M. (2011). On the use of paintings and tapesteries as sound absorbing materials. Forum Acusticum, Aalborg (pp. 1-4).

Martellotta, F., Cirillo, E., Carbonari, A., \& Ricciardi, P. (2009). Guidelines for acoustical measurements in churches, Applied Acoustics, (70), 378-388.

https://doi.org/10.1016/j.apacoust.2008.04.004

Marciniak, P. (2010). Doświadczenia modernizmu. Architektura $i$ urbanistyka Poznania w czasach PRL. Poznań: Wydawnictwo Miejskie (in Polish).

Odeon (version 2011). Room Acoustics Software, version 11. Combined edition by Christensen C. L., Odeon A/S, Scion DTU, Lyngby, Denmark.

Queiroz de Sant'Ana, D., Trombetta Zannin, P. H. (2011). Acoustic evaluation of a contemporary church based on in situ measurements of reverberation time, definition, and computer-predicted speech transmission index, Building and Environment, (46), 511-517.

Raczkowska, M. (2001). Rataje i Żegrze, Kronika Miasta Poznania, pod redakcja Jacka Wiesiołowskiego. Poznań: Poznańska Drukarnia Naukowa (in Polish).

Rychtáriková, M., Musabuda, M., \& Ohrablo, F. (2003). Evaluation of a modern catholic church by acoustical software based on the ray-tracing method. Slovak Journal of Civil Engineering, (3), 21-25.
Schenone, C., Borelli, D., Pittaluga, I. (2016, September). Numerical and experimental acoustical analysis of a contemporary modern church. Proceedings of the 22nd International Congress on Acoustics, Buenos Aires (pp. 1-10).

Sobczak, J. (2006). Kościoły Poznania. Poznań: Wydawnictwo Debiuty (in Polish).

Soeta, Y., Ito, K., Shimokura, R., Sato, S., Ohsawa, T., \& Ando, Y. (2012). Effects of sound source location and direction on acoustic parameters in Japanese churches. The Journal of the Acoustical Society of America, 131, 1206-1220. https://doi.org/10.1121/1.3676697

Sygulska, A. (2014). Acoustic investigations of the contemporary churches in Poznań, Vibrations in Physical Systems, 26, 281-288.

Sygulska, A. (2015). Contemporary two-storey churches - acoustic investigations, Journal of Architecture and Urbanism, 39(2), 140-148. https://doi.org/10.3846/20297955.2015.1056444

Weitze, C. A., Rindel, J. H., Christensen, C. L., \& Gade, A. C. (2002, September). The acoustical history of Hagia Sophia revived through computer simulation. Proceedings of the Forum Acusticum, Seville, Spain.

Wróblewska, D., \& Kulowski, A. (2007). Czynniki akusty$k i w$ architektonicznym projektowaniu kościołów. Gdańsk: Wydawnictwo Politechniki Gdańskiej (in Polish). 